Hsu Minna (Orcid ID: 0000-0003-0275-5186)

Howitt Richard (Orcid ID: 0000-0003-3769-4678)

\title{
Voluntary immobility and existential security in a changing climate in the Pacific
}

\author{
Carol Farbotko ${ }^{1}$ and Celia McMichael ${ }^{2}$
}

1. CSIRO, CSIRO Ecosystem Sciences, Research Scientist <carol.farbotko@csiro.au>

2. School of Geography, The University of Melbourne.

Abstract. With the expectation of adverse climate change impacts, some (often majority) Indigenous populations of the Pacific are expressing a preference to remain on Indigenous lands for cultural and spiritual reasons. In some cases, Indigenous people express preparedness to die on traditional territory rather than relocate, representing a new type of agency and resistance to dispossession. This is a prominent politics of place of relevance to emerging debates and decision-making around retreat and relocation. If climate change is experienced by populations as an existential threat to culture, identity and place-based connections, voluntary immobility can be an important adaptation strategy that helps to strengthen cultural and spiritual resilience among those facing the prospect of a lost homeland. This paper argues that voluntary immobility decisions need ethically robust and culturally appropriate policies and practices, particularly when a site is deemed by external experts to be no longer fit for human settlement. National governments, civil society groups, international organisations and donors will need to: engage in culturally meaningful dialogue with communities about relocation and immobility; respect, protect, and fulfil the rights of 'immobile' people and those on the move; and confirm that in situ adaptation options have been exhausted.

This is the author manuscript accepted for publication and has undergone full peer review but has not been through the copyediting, typesetting, pagination and proofreading process, which may lead to differences between this version and the Version of Record. Please cite this article as doi: 10.1111/apv.12230

This article is protected by copyright. All rights reserved. 
Keywords: relocation, immobility, migration, climate change, adaptation, Pacific, small island states, Indigenous

\section{Introduction}

Among many Pacific Island populations, climate change impacts are understood and represented as a significant threat to contemporary culture, spirituality and identity (Loeak, 2015; Nunn and Kumar 2018; Tiimon, 2011; Rakova, 2009). This threat is felt in low-lying coastal areas and small island states where communities face a possible future without a homeland to physically inhabit due to sea-level rise and associated coastal degradation. These are among the 'first and worst' places to be affected by climate change (Betzold, 2015; Nurse et al., 2014). Direct experiences of sea-level rise in small island states include storm surges, coastal inundation, coastal erosion or deposition, and saltwater intrusion of surface and ground-waters (IPCC, 2014; Nurse et al., 2014). Other climate impacts in the Pacific include altered rainfall patterns, extreme weather events, increasing air and seasurface temperatures, coral bleaching, reef degradation, human health challenges and changing crop yields and fish stocks (McMillen et al., 2014; Nurse et al., 2014; Janif et al., 2016).

Three primary strategies are usually proposed in response to sea-level rise: protect, accommodate and retreat. 'Protect' refers to use of defensive measures - such as sea-walls, and dune restoration - to protect the land from the sea and reduce the probability of adverse sea-level rise impacts. 'Accommodate' refers to use of accommodation measures in 
living and working practices - such as risk-based insurance, early warning systems, or improved drainage - to reduce sensitivity and exposure to sea-level rise (but not attempt to prevent flooding). 'Retreat' refers to migration or relocation away from sites of vulnerability such as low-lying coastal areas (Foresight, 2011; Hino et al., 2017; Nicholls et al., 2011).

In Pacific atoll island states, such as Tuvalu and Kiribati, all settlements are low-lying and coasts have been occupied by communities since first inhabited. In high Pacific Islands, it is noteworthy that some inland traditional settlements were encouraged to move to coastal fringes by colonial and religious authorities and more recently to engage in coastal tourism (Barnett and Campbell, 2010; Nurse et al., 2014). ${ }^{1}$ Whether due to colonial or traditional histories or a mixture, many Pacific Islanders reside in low-lying areas identified as vulnerable to sea-level rise. Due to anticipated social, cultural and economic costs, retreat is often considered undesirable both by community members and national governments (Campbell and Warrick, 2014; McNamara and Des Combes, 2014). Official policy in Kiribati and Tuvalu, for example, posits retreat as the least preferred adaptation option, given that it would likely involve international migration (Office of the President Government of Kiribati, n.d.; Government of Tuvalu, 2012). Further, while some individuals and households retreat for climate-related and other reasons (Campbell and Warrick, 2014), the majority are

\footnotetext{
${ }^{1}$ For example, in the Torres Islands in the northernmost part of the Vanuatu archipelago, while most islanders live near the coast this has not always been the case. In the 1870s, missionaries encouraged the relocation of converts from villages spread over the islands' inland plateaus into larger villages in coastal areas, which allowed for easier access by sea and (inadvertently) enabled transport via ships of people recruited for manual labour in Australia. The Torres Islanders' location in accessible coastal locations then drew them further into the cash economy. In these new coastal locations Torres Islanders are now more sensitive to environmental changes in coastlines than when living further inland (Siméoni and Ballu, 2012).
} 
staying in place at least for the foreseeable future, with communities widely adopting in situ 'protection' and 'accommodation' adaptation measures such as improved drainage and planting mangroves (Mortreux and Barnett, 2009). Meanwhile, relocation of coastal villages and settlements is anticipated, and is being implemented in some Pacific Island countries including Fiji, Vanuatu and the Solomon Islands (Hino et al., 2017; McMichael et al., 2019).

This paper considers the Pacific Island context and argues for greater recognition and understanding of voiced preferences for immobility in a changing climate, in the face of uninhabitability. It highlights the importance of community agency in retreat debates and decision-making as a matter of climate justice. For some people in the Pacific Islands it is culturally, spiritually and philosophically impossible to countenance the possibility of life without their current homeland to live in or return to. Indigenous communities, often with multi-generational cultural attachments to place, are threatened by potential and realised loss of homelands, even as these attachments are changing and unfolding over time (Stoffle and Arnold, 2003). In this context, the phenomenon of voluntary immobility requires research and policy attention.

Beyond the Pacific Island context, historically and geographically diverse examples of population immobility in sites experiencing environmental change or decline have been documented. For example, archaeological evidence suggests that during the mid-Holocene, about 9,500 years ago, the Flinders Island Aboriginal population became increasingly isolated as post-glacial sea-level rise cut off the Furneaux region from mainland Tasmania and the population did not survive, potentially due to localised water shortages (Sim and 
West 1999 p. 431). And in the small but emerging area of research on contemporary environmental change and immobility, some research has considered 'trapped' populations that cannot move, such as populations affected by Hurricane Katrina in New Orleans or severe droughts in Burkina Faso and Ghana (Zickgraf, 2018). Nonetheless, debate on climate change-related retreat has been relatively quiet on immobility, and particularly voluntary immobility (Zickgraf, 2018). Zickgraf (2018) notes a sedentary bias, a normalising of immobility: those who choose to remain in one place are deemed to be unproblematic and unworthy of academic and policy attention, whereas the 'problem' of environmental migration represents an out-of-the-ordinary response to crisis. As Zickgraf writes, "the inability to migrate, failed migration or a lack of migration aspirations are excluded from our narratives on the environment-mobility nexus" (2018: 72).

While all immobility involves choices and constraints, immobility broadly encompasses a spectrum of agency ranging from the voluntarily to the involuntarily immobile. While the conceptual line between voluntary and involuntary immobility is blurry, the notion of voluntary immobility refers broadly to those who choose to stay and trapped populations or the involuntarily immobile are those who are forced to stay. Within this spectrum of immobile populations, the research and policy focus has been on trapped populations (Black and Collyer, 2014; Foresight, 2011). The concept of trapped populations gained prominence in 2011 with the release of the UK Government's Migration and Global Environmental Change Foresight report (Foresight, 2011). It refers to impoverished people who are unable to move from environmentally high-risk areas due to lack of resources required to move, with this socio-economic vulnerability further amplified by the erosion of livelihoods via 
climate change impacts (Black and Collyer, 2014; Foresight, 2011; Nawrotzki and DeWaard, 2018). The term trapped populations, however, does not acknowledge people's preference or right to stay in a place that others may consider to be environmentally high-risk (AyebKarlsson et al., 2018; Black and Collyer, 2014). As Ayeb-Karlsson et al. (2018) caution, labelling a person or population as 'trapped' can, like the term 'vulnerable', potentially reduce recognition of agency and thus limit independence and self-determination.

The notion of voluntary immobility commences with the perspectives, agency and rights of people who do not want to leave their homes and homelands. The notion is conceptually challenging because it is difficult to distinguish between not wanting and not being able to retreat, people's judgement about whether they want or need to move can change over even short periods of time, and views can differ within households and communities (Black and Collyer, 2014; Zickgraf, 2018). Further, few mobility decisions can be defined as entirely voluntary or involuntary (Wilmsen and Wang, 2015), with other factors coming into play including coercion, asymmetrical information flows, political context, and economic and social barriers and facilitators. Nonetheless, there are populations who do not appear 'trapped' and yet who do not intend to move in response to environmental threats (be they biophysical realities, scientific forecasts, or other discourses of environmental future). In the context of environmental change, we suggest voluntary immobility refers to an informed, freely indicated preference to remain in sites where there is, or is expected to be, high vulnerability to environmental risk. 
While there is emerging discussion of immobile populations within environmental migration scholarship (c.f. Adams 2016; Black \& Collyer 2014; Foresight 2011; Zickgraf et al., 2016), there has been limited empirical research. Many examples come from retrospective consideration of case studies rather than intentional focus on immobility in research design, and the overwhelming focus is on 'trapped' populations with limited consideration of voluntary immobility (Zickgraf, 2018). In this paper, we explore references to voluntary immobility made in various contexts in the Pacific islands as emerging indications of voluntary immobility that require further research (c.f. Stoffle and Arnold, 2003). First, we consider guiding principles of participation and informed consent that have emerged from the broader field of displacement and resettlement. Second, the paper considers the cultural politics of climate risk and relocation in the Pacific Islands, where populations are often highly mobile yet have strong attachments to place. Third, drawing on a range of accounts of voluntary immobility from various Pacific Island contexts - including Tokelau, Fiji and Tuvalu - voluntary immobility is discussed as a complex politics of place. Finally, ethically robust and culturally engaged ways to support voluntarily immobile communities are highlighted, with a focus on processes that can ensure the rights and dignity of communities who choose not to relocate.

\section{Participation and informed consent in relocation planning and implementation}

Research has widely found that populations experiencing involuntary and government-led relocations - e.g. development-forced displacement and resettlement (DFDR) to make way for dams, hydro-electricity schemes, or urban expansion - experience negative outcomes

This article is protected by copyright. All rights reserved. 
(Maldonado et al., 2013; Wilmsen and Webber, 2015). Relocation risks include loss of land, employment, shelter, and access to common resources; economic marginalization; increased morbidity and mortality; food insecurity; disrupted social networks; and negative cultural and psychological impacts (de Sherbinin et al., 2011; Cernea, 2000; Donner, 2015). A commonly referred to example of forced relocation in the Pacific Islands is that of the Banabans who were relocated from Banaba Island to Rabi Island in Fiji (a distance of $3,200 \mathrm{~km}$ ) by the British Government in 1945 to make way for commercial interests around high-grade phosphate mining (a component of fertilizers). The relocated Banabans experienced significant challenges restoring their livelihoods as they were not familiar with managing land animals, shallow-reef fishing, or agricultural crops. Phosphate mining on Banaba Island ended in 1979 , with the impacts of mining affecting more than $90 \%$ of the island's surface area leaving virtually no possibility for the Banabans to return. This relocation occurred in the context of colonialism and was carried out with coercion in support of commercial interests and with little concern for affected communities (Campbell, 2010; Ferris, 2012). It presented risks to livelihoods, employment, economic status, food security, social networks and identity.

For climate change-related relocations, it is often assumed that there are similar risks to DFDR. Drawing on the DFDR literature, de Sherbinin et al. (2011: 456) state that 'resettlement should only be considered in cases where in situ adaptation is impossible'. Whether or not this principle should apply in all circumstances perhaps should remain open to further research. Research with communities in the context of climate change tends to be undertaken only once decisions have been made to relocate. Very little is known about the 
deliberations and debate that lead to these decisions. Some communities, then, may be keen to move earlier rather than later in the context of climate change but need to wait, for example, until international or national-scale processes are in place. Local knowledge and community-scale governance should be taken into account here, potentially providing better overall development and adaptation outcomes in the long run. In this vein, Koslov (2016) argues that emerging cases of community-driven retreat and relocation away from places that are vulnerable to flooding and sea-level rise are different to the often deeply impoverishing experiences of DFDR that are typically top-down interventions that displace people in the name of development and progress (Koslov, 2016). Community-led relocation has the potential to 'democratize and transform space and place' rather than contribute to impoverishment (Koslov, 2016: 381). Perhaps most importantly, the circumstances under which climate-related relocation will prove adaptive or maladaptive will depend on the circumstances of the community, including institutional support.

Certainly, there are increasing calls for relocation planning to closely involve the people affected (Gharbaoui and Blocher, 2016; Lopez-Carr and Marter-Kenyon, 2015). Gharbaoui and Blocher (2016) argue that planned relocation must be conducted with the informed consent of a target community and with planning support by government and/or international development partners. Informed consent, in turn, is possible following consultation and communication, with time for reflection and dialogue, particularly given the diversity of views within and between Pacific Island communities (c.f. Nunn et al. 2014). Communities should have time to voice their needs, debate differing perspectives, and make substantive contributions to relocation processes - deciding critical questions such as 
whether, when, where, how and who to relocate - and experience a strong sense of involvement and ownership.

Informed consent to relocation, however, may not be forthcoming in certain situations. For example, even where in situ climate adaptation is deemed impossible by governmentappointed planners, community members may decide that relocation is unacceptable. An ethically vexed situation may arise if people choose to remain in places deemed by planners as having exhausted in-situ adaptation options. The Pacific is a place where such intractable situations are arising, and are starting to be considered a matter of climate justice (Cooper 2017; Farbotko et al. 2018). National governments, civil society and communities are engaging in dialogue about ways forward when in-situ adaptation seems impossible and yet communities do not want to relocate.

\section{Indigeneity, mobility and place in the Pacific}

Pacific Islanders, while often highly mobile, have strong attachments to place (Charan et al., 2017). Indeed, land is crucial to vanua, fenua, hanua, fanua, whenua - almost the same word from Papua New Guinea to New Zealand - which refers to both a people and a place: 'the ground of belonging, the locus of being [Indigenous in the Pacific], the means of livelihood and the nurturer of life' (Havea, 2007: 51). Pacific people also have a proud history of ocean voyaging and navigating (Farbotko, 2012). It was only through their knowledge of seafaring that the widely dispersed islands of the Pacific were settled, long before other civilisations had developed ocean navigation systems (Finney, 2003). Land and ocean are thus both crucial to Pacific indigeneities, expressive of a dialectical relation 
between 'roots and routes' (Jolly, 2001; Clifford, 2001; Hau'ofa, 1993 and 1998). This interconnection can be understood as hundreds of years of dwelling in a harmonious way on ocean and land, a connection forged by the historically significant voyaging canoes. The world of the Pacific Islander ancestors was perceived in different spatial terms to those of Western worldviews. Voyaging was not only about transit between islands: sometimes these voyages were accidental, sometimes they were about suicide, or at least, a desire to be at sea without thought as to the consequences in terms of life and death (Firth 1961). Some were for exploration, population control, warfare, exile, trade, connecting kin. Some were ambivalent. But in all these voyages, the Pacific navigation system using stars, ocean, wind and birds, the canoe was perceived as the still point; it was islands and horizons that were in motion (Lewis 1972; Firth 1961; Kennedy 1929; Finney ; Kyselka 1997). Indigenous attachment to place in the Pacific, and movement from, to and between islands, was not and still today is not fixed, but is a way of living in and being part of a moving world, unfolding cycles of life in an oceanic environment (Māhina 2008; Teaiwa 2018). For example, Polynesian scholars such as H.O. Māhina have theorised indigenous attachment to place through related concepts such as fonua and vanua that enfold the past, the present and the future:

Of the many highly refined Moana (Pacific Ocean) concepts and practices is the truly sophisticated pan-Moana idea and praxis fonua, meaning land and its people, which variously exists throughout the Moana as vanua, fanua, hanua, honua, fenua, enua and whenua, amongst others... Besides fonua as pointing to the land-and-its-people, it also stands for the mother's placenta (fonua) and the graves of the dead (fonua).

This article is protected by copyright. All rights reserved. 
As a philosophy of life, a mode of operation, fonua manifests itself on two distinct but continuous levels. On the universal level, fonua entails the dialectically changing formal, substantial and functional relationships within and between nature, mind and society... On the unique level, however, fonua espouses the historically shifting ecological, psychological and sociological connections within and across fonua (birth), fonua (living) and fonua (death), as conflicting physical, emotional and human processes of eternal cycle and exchange (Māhina, 2008).

Pacific notions of indigeneity, such as fonua, are both ancient and adapting, invoking similarly complex place-based relations and mobility, multiplicity, and interconnection today, encapsulated in notions such as the expansive indigenous geography 'our sea of islands' (Hau'ofa, 1993 and 1998; Stratford et al., 2013; Teaiwa 2018). Culture, in such accounts, is dynamic and flexible. The ways in which people form relations with people, and with the world, are always changing, unfolding over time. On the other hand, it is not possible to deny the importance of the past, as the past deeply informs indigenous modes of resistance to what are often problems of imperialism, as Hawaiian scholar Trask explains clearly:

We know our future lies in the ways of our ancestors, not in the colonial world of haole experts...We do not need, nor do we want, to be "liberated" from our past because it is the source of our understanding of the cosmos and of our mana (Trask, 1991, 164).

This article is protected by copyright. All rights reserved. 
In the context of climate change, Pacific indigeneity and spirituality are known to be important cultural resources for those at risk, helping to navigate an often tenuous balance between hope and despair (Havea et al., 2018; Teaiwa 2018). Teaiwa specifically reflects on the dialectic of attachment to place and mobility in the context of climate change and potential displacement:

While movement is an inherent part of the Pacific way, simultaneously there are values and practices that ground and embed Pacific peoples deeply in their ancestral landscapes and seascapes. Diaspora and indigeneity are both important in Oceania" (Teaiwa 2018, 63).

Further, Teaiwa $(2018,69)$, who is part-Banaban, goes on to draw on the history of displacement of the Banabans due to phosphate mining as follows:

Neither the displacement of land nor people has reduced the attachment of Banabans to their ancestral home. Banaban identity has expanded to encompass a 'Fiji islander' identity and thus become more complex as it has for other Pacific migrants across and beyond Oceania.

Waterfront dwellings in the Pacific Islands are often the traditional home of communities with some dependence on subsistence livelihoods and long-standing connections to place, such as through fonua, which can include mobilities. Coastal environments offer potential for food acquisition, and flat terrain for agriculture and settlement (Nunn and Kumar, 2018). It seems likely that, prior to colonisation and globalisation, island communities affected by environmental change - e.g. cyclones, earthquakes, tsunamis - relocated, with the

This article is protected by copyright. All rights reserved. 
architecture of dwellings allowing them to be rebuilt with comparative ease. For example, there is some evidence that people of southern Pentecost island in Vanuatu have historically moved away from the coast in response to awareness of tsunami risk (following a tsunami), yet over time moved back to the coast where life is easier (Walshe and Nunn 2012).

Over the past 50-100 years there has been increased settlement in coastal zones and traditional attitudes becoming more aligned with those of colonisers that regard long-term settlements as normal and sustainable (Nunn and Kumar 2018). Added to this mix, there is a long history of involuntary relocations throughout the colonial era (Connell, 2012). Coastal communities, however, regardless of the specifics of their colonial encounter, are facing a new form of colonial dispossession: with historical and current negligible contributions to global greenhouse gas emissions, past successful colonial efforts to limit customary mobilities and increase sedentarism, mean that coastal communities in the Pacific Islands are, on the whole, facing disproportionately large climate change and colonial impacts, particularly coastal erosion, sea-level rise, and associated effects on coastal and marine socio-ecological systems (Edwards, 2014). In short, mobilities and immobilities in the region, both historical and contemporary, carrying the effects of (more or less) voluntary cultural and political change, environmental change and (more or less) imposed colonial governance, are in an overall deficit position when it comes to having their cultural, political and land rights respected.

Compounding these issues, there are further political forces influencing risk for populations of coastal areas in the Pacific Islands, such as climate change scepticism (Bettini, 2013). 
First, such populations may be victim-blamed for presuming to inhabit a vulnerable location (Barnett and Campbell, 2010). Second, the risk of sea-level rise and other climate change impacts is often reduced to the questions of 'to stay or to go', to 'live or to die' (Methmann and Oels, 2015). Within these binaries, a 'rational' response is typically assumed to be to go. These politics of place and mobility result in an ambiguous moral geography that imagines climate-affected mobile populations rationally needing to migrate, relocate or 'go' as climate impacts increase; at once placeless and yet also sufficiently emplaced to be somehow encroaching upon larger, wealthy states through unwanted or illegal migration, conflict, humanitarian crises and related pressures on foreign aid and national security budgets (Farbotko, 2018a; Hartmann, 2010).

Climate injustices such as these, however, can be and are being resisted. Climate vulnerable people in the Pacific Islands are mobilising, both literally and politically (Barnett, 2016). Concern about climate change impacts, commencing in the late 1980s, has been channelled into long-term lobbying in the context of the United Nations Framework Convention on Climate Change (UNFCCC). Pacific Island leaders have made consistent arguments at successive UNFCCC Conferences of the Parties (COP) for global reductions in greenhouse gas emissions, to reduce the risk of sea-level rise and other climate change impacts (de Agueda Corneloup and Mol, 2014; Ourbak and Magnan, 2017). Pacific Island leaders have been instrumental in building a sense of solidarity and alliance between climate-affected peoples and nations. Leaders and communities have also made the argument for international assistance in building adaptive capacity, to facilitate in-place adaptation to climate change, drawing attention to the unique contribution made by island cultures to global cultural 
diversity and the need for the international community to protect rights to selfdetermination, territory, and identity. Not only are elected representatives vocal and influential beyond their relative size in the COPs, grassroots advocacy for climate change mitigation and adaptation efforts is strong, particularly through performance arts and nonviolent direct action focusing on issues of justice and human rights (Steiner, 2015; McNamara and Farbotko, 2017). Steiner explains how Pacific islanders, through various artistic performances, have evoked 'the rich environmental heritage that their islands have nurtured, they have expressed what it would mean to lose that heritage and those islands, and they have called on all the world to work together to prevent further loss' (Steiner, 2015: 171). Generally, those at risk wish to participate in the pursuit of climate justice as resilient subjects, 'proactive, self-determining, and active agents of change' (Dreher and Voyer, 2015; see also Teaiwa 2018). They do not wish to be identified as vulnerable victims or 'climate refugees' (McNamara and Gibson, 2009).

\section{Emerging indications of voluntary immobility in the Pacific}

In this section, we consider emerging evidence of voluntary immobility intentions in the Pacific. We suggest voluntary immobility intentions are currently observable in speeches, stories and interviews that imagine and plan for the future, and other anticipatory adaptations that some Pacific people use to make sense of climate change. It should be noted that campaigns to raise awareness about climate change in the region over nearly

This article is protected by copyright. All rights reserved. 
two decades have been effective, particularly in low-lying atoll states. Farbotko (2018b) postulated that:

The most important issue, according to those voluntarily resisting mobility, is not 'where will we go?' or 'how will we survive?'; it is 'how do we maintain our identity and build pathways to a self-determined, resilient future?'. Voluntary immobility is an important coping device, helping to strengthen cultural and spiritual agency among those facing the loss of their homeland.

Expressions of voluntary immobility, therefore, are a way of politicizing place and asserting right to self-determination: a response to climate injustice, a way of reclaiming identity and of navigating a very difficult future. Farbotko, Lazrus and Stratford (2016: 535) found, during interview research with residents in Tuvalu, that there were voiced commitments to stay 'rooted in place' even when faced with an environmental future of possible inundation of their islands, and despite the widely accepted importance of mobility for livelihood diversification. There appeared to be 'sedimentation of sedentarist feelings' (2016: 535). Further:

There [was] a static and distinctly immobile relationship between people and island being imagined in the context of climate change. Permanent migration away from 'disappearing islands' [was] being expressed as an upheaval and rupture of a firmly territorial and rooted identity...the most emotionally charged narratives involve suggestions of a preference to die, rather than to leave, as climate change impacts become severe (2016: 540).

This article is protected by copyright. All rights reserved. 
For some people in Tuvalu, fenua is entrenched strongly in land as a response to climate change, and less in the mobile, exploring, oceanic worlds of their ancestors or even among the present forms of mobility such as migration to New Zealand (Farbotko, Stratford and Lazrus 2016).

A story originating in Tokelau demonstrates how expressions of voluntary immobility are a means for people to define a future that is historically, culturally and spiritually valuable. Farbotko (2018a) related a story told by a young Pacific climate activist to other Pacific islanders at a 'Pacific Climate Warrior' address in Brisbane in 2014:

Two decades ago, a foreign scientist visited a small Pacific island. He was a climatologist, and he spoke to the people there. His message was frightening and clear. On the eve of the new millennium, he said, the island would sink under the sea forever. The scientist left the island after that, never to be seen there again. On the night of the new millennium, the people of the island dressed in white. They gathered together on the beach. They sang hymns and prayed, waiting for the sea to rise up. They wanted to stay with their God, their land, their ancestors, and their ocean. The people waited on the beach till dawn. The island was still there, and the sea was no higher than usual. The people went back to their homes and thanked God for saving their island (Farbotko 2018a, np).

Vital to this story is the certainty of attachment to place and identity even as islands were to become uninhabitable. The difficult question of where islanders would go and who they would be in the face of climate change was answered simply: they would stay on their island, their home, and they would accept death if need be. The islanders did not leave

This article is protected by copyright. All rights reserved. 
before sea-level rise was expected to make their island uninhabitable. They did not exercise their legal right, as inhabitants of a territory of New Zealand, to leave Tokelau for New Zealand. They did not agitate for their island to be protected, perhaps through building a sea wall. In this story, the action taken by the islanders was to plan among themselves, agree that they would stay on the island, and accept the fate that was said to be coming. The islanders wanted to face the ocean as it rose to claim them and their island. They would do so peacefully, in white, in prayer, together and - importantly - on their terms, exercising their right of self-determination and voluntary immobility (Farbotko, 2018a).

It is ethically unsettling that in this young activist's narrative account of an imagined environmental future, the islanders chose to face death rather than leave. To be clear, this story is not indicative of the beliefs, values and plans of Pacific Island communities in general nor an account that represents shared or collective visions. Many communities do consider both in-situ adaptation and migration to be crucial in their climate change planning and articulations of voluntary immobility are not necessarily typical (e.g. Havea et al., 2018). However this story suggests that immobility in the face of climate risk - or, in this case, an imagined future of remaining in place - can represent a politically and culturally important choice to prioritise ancestral ties to place, identity, and religion.

Similar to the Tokelau story, other groups of Pacific people are expressing extremely strong ties to land, a preparedness to remain in place, or cultural or spiritual anxieties following a relocation. Charan et al. (2017) studied the relocation of a climate change-affected community in Fiji and observed strong links between culture, ancestors, community and 
place. They reported that culture, communal unity, and traditional obligations to ancestors have a significant impact on relocation planning and can even prevent communities moving. Nolet, also working with climate-impacted communities in Fiji, noted the links between culture, ancestors, community and place:

Strong ties exist between Fijian clans and the particular territorial areas (vanua) they are identified with. Relocating would mean breaking links with ancestors buried on these communal lands (2018: $\mathrm{np})$.

And a former Tuvaluan climate change activist, now migrated to Australia, shared his understanding of some of his fellow Tuvaluan citizens' preference to stay in Tuvalu even in the worst-case scenario:

No Tuvaluan wishes to be treated poorly. We would rather make our own choices. In fact, for many people in Tuvalu, there is a strong wish to stay on the islands no matter what climate change brings. Many would rather stay and die, than to migrate to another country or to be forced to go as a refugee (Kitara and Farbotko, 2017). Farbotko et al. (2016) also reported on one Tuvaluan woman's preference to die, rather than to leave, as climate change impacts become severe: 'We don't want to ... relocate to other countries, to burden them, because we have our own culture and we want to maintain that'. Further, she would be 'very sad ... [and] if the worst comes to the worst, I think I would rather just stay here and die. I don't want to leave my country' (see Farbotko et al., 2016). This woman expressed a double burden: not only did she face loss of land and cultural identity, but also felt she would be a burden as a migrant in another place. 


\section{Ethical approaches to voluntary immobility in relocation initiatives}

In this section, we draw on relocation projects underway in Fiji as part of adaptation planning by the Government of Fiji, to consider ways in which expressions of voluntary immobility can be heard, and taken into account. A statement from the Government of Fiji for COP23 indicated that rising sea-levels and saltwater intrusion from coastal flooding 'have made portions of the island nation uninhabitable and rendered much arable land unsuitable for agriculture, threatening communities' food security' (COP23 Presidency Secretariat, 2017). Several dozen Fijian villages and communities have been identified for possible relocation by the government, but communities have significant control over whether, where and how to relocate (Barnett and McMichael, 2018; McNamara and Des Combes, 2014; Republic of Fiji, 2014).

Emerging relocation experiences of low-lying iTaukei (Indigenous) villages indicate that in addition to key 'technical' elements- such as suitable physical dwellings and ongoing economic viability - valued and positive elements of the process include continued presence on traditional lands and communal land ownership, use of and respect for customary governance processes and Indigenous protocols, maintenance of a communal sense of identity, meaningful deployment of community's cultural and political skills, and community knowledge and decision-making (Charan et al., 2017; Gharbaoui and Blocher, 2016; Gharbaoui and Blocher, 2018). The emphasis on community involvement in emerging relocation initiatives in Fiji is partly due to the fact that the national government is mindful 
and respectful of customary village-level governance and Indigenous protocols (Charan et al., 2017; McMichael et al., forthcoming; McNamara and Des Combes, 2014).

Importantly, lived experience of coastal erosion, flooding and saltwater intrusion provide impetus for relocation and retreat among residents of some low-lying villages. And yet in such contexts, there are different experiences and views within communities; many older members of communities, for example, express greater reluctance to relocate than younger people. Yet environmental changes and challenges make it difficult to remain. One older woman from Vunidogoloa - a relocated village - described (to McMichael) how experiences of flooding led to her agreeing that relocation was necessary:

Down there, when it is heavy rain it came inside the village. It came from the sea and the river as well. My house was flooded. I was rushing inside the house when it was flooded. It made it easy for me to agree to move.

Vunisavisavi in Cakaudrove Province and Narikoso village in Kadavu Province are also engaged in relocation planning and implementation. There, both lived and anticipated experiences of coastal erosion and flooding underscore the widely held view that relocation is a necessary and appropriate response.

Yet voluntary immobility is widely discussed and preferred by some residents of low-lying villages in Fiji. Some villagers described reluctance to relocate, particularly members of older generations. As a village leader of the relocated village of Vunidogoloa explained: Low-lying coastal areas were advised to move to higher land. So that's the time it's my role to say all of us are taken to safer place. When it comes to older people, some 
80 s and 90s, I said 'we have been advised to move to higher place because of flooding and sea-level rise'. They tell me, 'if you want to move you move, you leave me alone in my house. If I die, I die with my house on my land'... It was not easy for them [villagers] to relocate, because the whole of their lives they were living there, from their great-great-great-grandfather. So we let the older people die there before we decided to relocate. It took years. We started off in 2006. We finished in 2014. Eight years ... But we are very safe, we are very fortunate this generation to move to this higher village.

Many expressed a preference to remain in their villages where they belong, even in the face of environmental risks. One man from Tokou, a low-lying village in Lomaiviti Province, described his reluctance to relocate even as protection measures such as sea-walls failed and flooding increased: 'At the moment we can see that the sea wall is there and breaking. The waves are coming. But relocation, that is a very big thing for us'. And in Vunisavisavi in Cakaudrove Province, four new houses have been built that are set back from the high tide and inundation zone. One woman explained that this phased retreat was preferable to relocation of the entire village: 'We could go up that side, on top. But problem is we don't want to move. Some want to stay, some want to move. Older people want to stay. They are born here.' Several residents explained that their village is the original site of the Paramount Chief of Cakaudrove and that the ruins of this chiefly village home remain near the foreshore. According to Vunisavisavi residents, they must stay at the current village site because of their traditional obligations to protect these ruins. These accounts highlight that 
relocation can be perceived to threaten belonging, place attachment, and custodial responsibilities, as people grapple with the question of whether to remain in vulnerable sites where they feel they belong or move away from sites of environmental risk.

Explanations for populations remaining in the face of environmental risk have focused on financial barriers to migration, rather than socio-psychological or affective aspects that constrain decisions to migrate (Adams, 2016). In these villages in Fiji, expressions of a preference to live (and even die) with climate risks in places they belong highlight the complex concerns of islanders, linking the dynamics of spirituality, culture, people and place. Recognising such concerns, and communicating and planning with Pacific people in ethically and culturally appropriate ways, presents international and national policy challenges. Cultural and emotional needs, as well as material security, need explicit recognition and action in relocation efforts (Gharbaoui and Blocher, 2016). Arguably, a guiding principle is that the spectrum of choices available to climate vulnerable people should never be reduced to the question of 'to stay or to go' (Methmann and Oels, 2015). As a matter of climate justice, the onus is on development organisations, donors, national governments and other external actors to engage with the dynamic cultural politics of climate change, including Indigenous senses of belonging which may be expressed but not necessarily 'heard'. Finding the appropriate mix of cultural and emotional care with material well-being of people and place is crucial.

Relocation principles and conceptual frameworks must, as with adaptation planning more generally, address emotional and cultural relations with place (Charan et al., 2017). Themes 
of self-determination and voluntary immobility are referred to in various guiding principles and statements that focus on climate-related displacement and relocation, including: the 'Nansen Principles' and the 'Platform on Disaster Displacement' to guide responses to challenges raised by displacement in the context of climate change and other environmental hazards; 'The Peninsula Principles on Climate Displacement within States'; and UNHCR's document 'Protection and Planned Relocations in the Context of Climate Change, Guidance on Protecting People from Disasters and Environmental Change through Planned Relocation' (Ferris, 2011; Nansen Conference, 2011). These documents variously highlight that: planned relocation should be a measure of last resort after other adaptation measures have been considered and exhausted, although we note that this principle may not be appropriate in all contexts; and relocated persons should be informed, consulted and enabled to participate in decisions on when, whether, where and how planned relocation will occur. However, more complex themes of identity, attachment and belonging are not addressed (although acknowledged in the case of the Peninsula Principles).

Fundamentally, relocation should be a process in which people exercise cultural, political and communal rights rather than a top-down decision-making process focused primarily on technical, economic and physical considerations. Governments and adaptation specialists should not set the terms under which debate unfolds. As a matter of climate justice, they need to engage with communities in an emergent, sometimes contested politics of place. For communities considering relocation, the important question of how to sustain and redefine their Indigenous identity in a changing climate and build pathways to a selfdetermined, resilient future needs to be given space and time for reflection and debate. 
These issues cannot be reduced to questions of destination, livelihoods or the materialities of adaptation, as important as these may be (Charan et al., 2017). The best possible outcome for cultural identity and self-determination, as well as human development goals, must be pursued (see Howitt et al., 2011). This requires an openness on the part of governments (provincial, national, or international) and donor organisations to listen to and understand the existential as well as the practical concerns of communities, to respect and support decisions not to relocate, and to advance the cultural needs of communities that do relocate.

Voluntary immobility may be an important coping device, helping to strengthen cultural and spiritual agency among those whose homes and homelands are threatened. It may represent a form of resistance to the imaginary of catastrophic climate futures which undermines the case for in situ adaptation and development (Barnett and McMichael, 2018). There must be more ethically and culturally robust frameworks to support voluntary immobility, at sub-national, national and international scales. Policy responses need to be adaptable, to respect that cultural and spiritual attachments to particular places might adapt to a changing climate in ways that make sense within Indigenous belief systems, and that at the same time, such belief systems may be changing. Different types of support may be needed as political, legal, psychological, cultural, physical and economic conditions change (Farbotko, 2018b).

As livelihoods deteriorate, or if a new environmental disaster occurs, Pacific people should have opportunities to negotiate mobility and ties to place in ways that offer the greatest 
degree of cultural and livelihood security. Ways forward include: continuation of activities such as fishing and visiting sacred sites; siting of new dwellings, other buildings and infrastructure away from vulnerable sites so that physical retreat occurs gradually where possible; community projects focussed on artistic representations of mobility, immobility and the homeland in stories, performing and visual arts; formal documentation and preservation of cultural heritage; and embedding culturally appropriate topics associated with mobility and immobility in school curricula. It also likely involves dialogue between communities facing similar challenges, sharing emerging knowledge within, across and beyond the Pacific Islands (see Weber, 2015).

The issue of voluntary immobility raises a fundamental ethical challenge with which international and national policy frameworks must grapple: should national governments or other institutions support voluntary immobility even if likely to lead to risk to or loss of life, or should relocation be implemented against the will of those who have expressed a preference to remain? The Peninsula Principles state that 'no relocation shall take place unless individuals, households and communities (both displaced and host) provide full and informed consent for such relocation' (Displacement Solutions, 2013: 19). Accordingly, governing institutions should bear the evidentiary onus to ensure that individual and collective choices to remain are voluntary (Farbotko, 2018b). The Principles go on to say, however, that national governments should 'only require relocation to take place without such consent in exceptional circumstances when necessary to protect public health and safety or when individuals, households and communities face imminent loss of life or limb' (Displacement Solutions, 2013: 22). This is a highly vexed ethical and political issue, and one 
that has not yet been tested with (to our knowledge) no cases of enforced relocation (as opposed to temporary emergency evacuations) to prevent risk to health and life. Yet in either case, whether national governments support relocation or voluntary immobility, they retain important responsibilities to: respect, protect, and fulfil the human rights of people within their territory; engage in culturally sensitive dialogue with communities about the consequences of relocation and immobility; and confirm that all in situ adaptation options have been exhausted.

\section{Conclusion}

Climate justice requires careful consideration and responsiveness to voluntary immobility. Community, household and individual aspirations to stay need to be listed to and engaged with, deeply. Pacific communities are facing significant threats to culture, identity and agency, as they are themselves articulating; these threats may be as important, if not more so, than the risks typically associated with climate change and resettlement including risk to human health, livelihoods and property. Yet communities are also building cultural and political resilience in coastal settlements in a changing climate, sometimes in place and sometime by retreating. Further co-produced research with communities is needed, testing some of the options discussed in this paper and advancing ethical and empathetic dialogue on these issues.

Importantly, local perceptions of environmental risk are not always aligned with externally observed climate data (Zickgraf, 2018). Expressions of voluntary immobility demand that relocation planning includes sustained and deep dialogue between planners and

This article is protected by copyright. All rights reserved. 
communities, most especially when (external) experts deem resettlement to be 'necessary' but community members disagree. The community arguably have, through the right of selfdetermination and as a matter of climate justice, final say on whether or not resettlement is to occur, but they also need to have time and space to discuss the risks, identify trade-offs (e.g. some government services may no longer be available), and - likely together with national and international institutions - formulate long-terms plan for community development and well-being.

Where climate-related relocations are planned and realised, processes must be characterised by the protection and promotion of human rights and communal rights, including Indigenous rights and the right to self-determination. Voluntary immobility, where it is meaningful to a community, should be recognised at national and international scales of governance as an assertion of identity and cultural heritage, part of a community's capacity to adapt to climate change in self-determined ways. These are not 'trapped populations' but rather people and communities expressing a preference to remain in places that are simultaneously sites of climate risk and sites of cultural strength, resilience and belonging. Voluntary immobility in a changing climate demands that external partners engaged in relocation planning rethink adaptation to climate change in ways that support cultural resilience in the face of risk to homelands. Voluntary immobility requires deeper crosscultural dialogue, with specific attention paid to understanding and supporting cultural resources associated with belonging and place. Indeed, institutions will need to quickly, respectfully, empathetically and ethically adapt to the issue of voluntary immobility. 
Finally, if people have the right to voluntarily stay in places of risk, do governments have a duty to try and persuade them otherwise? This question is an ethically complex one that can only be answered by governments themselves, informed by deep and culturally sensitive dialogue in the form of genuine participatory planning. We believe the onus is on governments and other development and adaptation organisations to create the time and space for communities to be able to navigate difficult decisions with governments and their supporting organisations. Ultimately, communities need to feel a sense of ownership over which decisions are made, but also how they are made. Significantly more research is needed to co-design and co-develop planning tools in this space.

This article is protected by copyright. All rights reserved. 


\section{References}

Adams, H. 2016. “Why Populations Persist: Mobility, Place Attachment and Climate Change." Population and Environment 37 (4): 429-48.

Ayeb-Karlsson, S., C.D. Smith, D. Kniveton (2018) A discursive review of the textual use of 'trapped' in environmental migration studies: The conceptual birth and troubled teenage years of trapped populations, Ambio DOI 10.1007/s13280-017-1007-6

Barnett, J. (2017) The dilemmas of normalising losses from climate change: Towards hope for Pacific atoll countries, Asia Pacific Viewpoint 58(1): 3-13.

Barnett, J. and J. Campbell (2010) Climate change and small island states: Power, knowledge, and the South Pacific. Earthscan.

Barnett, J. and C. McMichael (2018) The effects of climate change on the geography and timing of human mobility, Population and Environment https://doi.org/10.1007/s11111018-0295-5

Bettini, G. (2013) Climate barbarians at the gate? A critique of apocalyptic narratives on 'climate refugees', Geoforum 45: 63-72.

Betzold, C. (2015) Adapting to climate change in small island developing states, Climatic Change 133(3): 481-489.

Black, R. and M. Collyer (2014) "Trapped" Populations: Limits on mobility at time of crisis, in S.F. Martin, S. Weerasinghe, and A. Taylor (eds.), Humanitarian crises and migration. London: Routledge.

This article is protected by copyright. All rights reserved. 
Campbell, J. (2010) Climate-Induced Community Relocation in the Pacific: The Meaning and Importance of Land, in J. McAdam (ed.), Climate Change and Displacement: Multidisciplinary Perspectives. Oxford and Portland, Oregon: Hart Publishing.

Campbell, J. and O. Warrick (2014). Climate Change and Migration Issues in the Pacific. Suva, Fiji: UNESCAP. Retrieved 28 February 2018, from website:

http://www.unescap.org/sites/default/files/Climate-Change-and-Migration-Issues-in-thePacific.pdf

Cernea, M. (2000) Risks, safeguards and reconstruction: a model for population displacement and resettlement, in M. Cernea and C. McDowell (eds) Risks and Reconstruction. Experiences of Resettlers and Refugees. Washington D.C.: World Bank. Charan, D., M. Kaur and P. Singh (2017) Customary Land and Climate Change Induced Relocation-A Case Study of Vunidogoloa Village, Vanua Levu, Fiji, in W. Leal Filho (ed.) Climate Change Adaptation in Pacific Countries: Fostering Resilience and Improving the Quality of Life. Springer International Publishing.

Clifford, J. (2001) Indigenous articulations. The Contemporary Pacific 13(2): 468-490.

Connell, J. (2012) Population Resettlement in the Pacific: lessons from a hazardous history?, Australian Geographer 43(2): 127-142.

COP23 Presidency Secretariat, 2017. COP23 Media Kit. Retrieved 28 February 2018, from website: https://cop23.com.fj/wp-content/uploads/2017/09/COP23-Media-Kit master.pdf.

This article is protected by copyright. All rights reserved. 
Cooper, J. (2018) 'Adaptation, or justice? Climate action in the Pacific' Commonwealth Foundation https://commonwealthfoundation.com/can-pacific-civil-society-bring-messagejustice-climate-change-narrative/

de Agueda Corneloup, I. and A.P. Mol (2014). Small island developing states and international climate change negotiations: The power of moral "leadership", International Environmental Agreements: Politics, Law and Economics 14(3): 281-297.

de Sherbinin, A., M. Castro, F. Gemenne, M.M. Cernea, S. Adamo, P.M. Fearnside, G. Krieger, S. Lahmani, A. Oliver-Smith, A. Pankhurst and T. Scudder (2011) Preparing for resettlement associated with climate change, Science 334(6055): 456-457.

Displacement Solutions, 2013. The Peninsula Principles on Climate Displacement Within States. Geneva, Switzerland: Displacement Solutions. Retrieved 26 February 2018, from website: http://displacementsolutions.org/wp-content/uploads/2014/12/PeninsulaPrinciples.pdf

Donner, S.D. (2015) The legacy of migration in response to climate stress: learning from the Gilbertese resettlement in the Solomon Islands, Natural Resources Forum 39(3-4): 191-201.

Dreher, T. and M. Voyer. (2015) Climate refugees or migrants? Contesting media frames on climate justice in the Pacific, Environmental Communication 9(1): 58-76.

Edwards, J. (2014). Climate justice and the Pacific conference of churches: Moving the relocation agenda in the Pacific, in L. Andrianos, J. W. Sneep, G. Kerber, \& R. Attfield (eds.), 
Sustainable alternatives for poverty reduction and eco-justice. Newcastle, England:

Cambridge Scholars Publishing.

Farbotko, C. (2012) Skilful seafarers, oceanic drifters or climate refugees? Pacific people, news value and the climate refugee crisis, in K. Moore, B. Gross, T. Threadgold (eds.), Migrations and the Media. New York: Peter Lang Publishing.

Farbotko, C. (2018a) Climate Change and Island Populations, in Steele, B.J. and Heinze, E.A. (eds.), Routledge Handbook of Ethics and International Relations. London: Routledge.

Farbotko, C. (2018b) Voluntary Immobility: Indigenous Voices in the Pacific, Forced Migration Review 57: 81-83.

Farbotko, C., E. Stratford and H. Lazrus (2016) Climate migrants and new identities? The geopolitics of embracing or rejecting mobility. Social \& Cultural Geography 17(4): 533-552.

Ferris, E. (2011) Planned relocations, disasters and climate change. Brookings-LSE Project on Internal Displacement. Retrieved 12 December 2017, from website:

https://www.brookings.edu/wpcontent/uploads/2016/06/1110_relocation_disasters_cc_ferris.pdf

Ferris, E. (2012) Protection and Planned Relocations in the Context of Climate Change.

Geneva: United Nations High Commissioner for Refugees.

Finney, B. (2003) Sailing in the wake of the ancestors: Reviving Polynesian Voyaging. Bishop Museum Press.

Firth, R. (1961). Suicide and risk-taking in Tikopia society. Psychiatry, 24(1), 1-17.

This article is protected by copyright. All rights reserved. 
Foresight, (2011) Migration and global environmental change: final project report. London: The Government Office for Science.

Gharbaoui, D. and J. Blocher (2016) The reason land matters: Relocation as adaptation to climate change in Fiji Islands, in A. Milan, B. Schraven, K. Warner, N. Cascone (eds.) Migration, Risk Management and Climate Change: Evidence and Policy Responses. Springer. Gharbaoui, D. and J. Blocher (2018). Limits to Adapting to Climate Change Through Relocations in Papua-New Guinea and Fiji, in W. Leal Filho and J. Nalau (eds.) Limits to Climate Change Adaptation. Springer.

Government of Tuvalu, (2012) Te Kaniva: Tuvalu Climate Change Policy 2012. Government of Tuvalu. Retrieved 12 December 2017, from website: http://www.sprep.org/attachments/Climate_Change/Te_Kaniva_Tuvalu_Climate_Change_P olicy_2012_Eng_Translation.pdf.

Hartmann, B. (2010). Rethinking climate refugees and climate conflict: rhetoric, reality and the politics of policy discourse, Journal of International Development 22(2): 233-246.

Hau'ofa, E. (1993) Our Sea of Islands, in E. Waddell, V. Naidu and E. Hau'ofa (eds.) A New Oceania: Rediscovering Our Sea of Islands. Suva, Fiji: University of the South Pacific and Beake House.

Hau'ofa, E. (1998) The Ocean in Us. The Contemporary Pacific 10(2): 391-410.

This article is protected by copyright. All rights reserved. 
Havea, J. (2007) The vanua is fo'ohake [the land is lying on its back], in J. Webb, J. and K. Nandan (eds.) Writing the Pacific. Suva, Fiji: Pacific Writing Forum and University of the South Pacific.

Havea, P.H., S.L Hemstock, H.J. Des Combes and J. Luetz (2018) “God and Tonga Are My Inheritance!" Climate Change Impact on Perceived Spirituality, Adaptation and Lessons Learnt from Kanokupolu, 'Ahau, Tukutonga, Popua and Manuka in Tongatapu, Tonga, in W. Leal Filho (ed.) Climate Change Impacts and Adaptation Strategies for Coastal Communities. Springer.

Hino, M., C.B. Field and K. Mach (2017) Managed retreat as a response to natural hazard risk, Nature Climate Change. 7: 364-370.

Howitt, R., O. Havnen and S. Veland (2012) Natural and Unnatural Disasters: Responding with Respect for Indigenous Rights and Knowledges. Aboriginal Policy Research Consortium International (APRCi). Paper 167.

IPCC, (2014) “Climate Change 2014: Synthesis Report. Contribution of Working Groups I, II and III to the Fifth Assessment Report of the Intergovernmental Panel on Climate Change." RK Pachauri and LA Meyer (eds.), IPCC, Geneva Janif, S., P. Nunn, P. Geraghty, W. Aalbersberg, F. Thomas and M. Camailakeba (2016) Value of traditional oral narratives in building climate-change resilience: insights from rural communities in Fiji. Ecology and Society, 21(2): 7

This article is protected by copyright. All rights reserved. 
Jolly, M. (2001) On the Edge?: Deserts, Oceans, Islands, The Contemporary Pacific 13(2):

417-466.

Kitara, T. and C. Farbotko (2017) I'm not a climate refugee, Uneven Earth, Tracking

Environmental Justice, Retrieved 4 May 2018, from website:

http://unevenearth.org/2017/10/im-not-a-climate-refugee/

Koslov, L. (2016) The case for retreat, Public Culture 28(2): 359-387.

Kyselka, W. (1987). An ocean in mind. University of Hawaii Press.

Lewis, D. (1994). We, the navigators: The ancient art of landfinding in the Pacific. University of Hawaii Press.

Loeak, M. (2015) On the road to Paris \#COP21 Milañ Loeak Republic of the Marshall Islands, Te Wharepora Hou, Retrieved 26 October 2016, from website:

https://tewhareporahou.wordpress.com/2015/10/06/on-the-road-to-paris-cop21-milanloeak-republic-of-the-marshall-islands/

Lopez-Carr, D. and J. Marter-Kenyon (2015) Manage climate-induced resettlement, Nature 517(7534): 265.

Māhina, H.O. 2008. "From Vale (Ignorance) to 'ilo (Knowledge) to Poto (Skill) the Tongan Theory of Ako (Education): Theorising Old Problems Anew." AlterNative: An International Journal of Indigenous Peoples 4 (1): 67-96.

This article is protected by copyright. All rights reserved. 
Maldonado, J.K., C. Shearer, R. Bronen, K. Peterson, H. Lazrus (2013) The impact of climate change on tribal communities in the US: displacement, relocation and human rights.

Climatic Change 120: 601-614.

McMichael, C., C. Farbotko and K. McNamara. (2019) Climate Change and Migration in the Pacific: Fiji, Kiribati and Tuvalu, in The Handbook of Migration Crises, C. Menjivar et al. (eds.) Oxford University Press.

McMillen, H.L., T. Ticktin, A. Friedlander, S.D. Jupiter, R. Thaman, J. Campbell, J. Veitayaki, T. Giambelluca, S. Nihmei, E. Rupeni, L. Apis-Overhoff, W. Aalbersberg, and D.F. Orcherton. (2014) Small islands, valuable insights: systems of customary resource use and resilience to climate change in the Pacific, Ecology and Society 19(4): 44.

McNamara, K.E., and H.J. Des Combes (2016) Planning for Community Relocations Due to Climate Change in Fiji, International Journal of Disaster Risk Science 6(3): 315-19.

McNamara, K.E. and C. Farbotko (2017) Resisting a 'doomed' fate: An analysis of the Pacific Climate Warriors, Australian Geographer 48(1): 17-26.

McNamara, K.E. and C. Gibson (2009) 'We do not want to leave our land': Pacific ambassadors at the United Nations resist the category of 'climate refugees, Geoforum 40(3): 475-483.

Methmann, C. and A. Oels (2015) From 'fearing' to 'empowering' climate refugees: Governing climate-induced migration in the name of resilience, Security Dialogue 46(1): 5168.

This article is protected by copyright. All rights reserved. 
Nansen Conference, (2011) Climate Change and Displacement in the 21st Century. Oslo:

Nansen Conference 2011. Retrieved 11 February 2017, from website:

http://d2530919.hosted213.servetheworld.no/expose/global/download.asp?id=2280\&fk=1 633\&thumb $=$.

Nawrotzki, R.J. and J. DeWaard (2018) Putting trapped populations into place: climate change and inter-district migration flows in Zambia, Regional Environmental Change 18(2): 533-546.

Nicholls, R.J., N. Marinova, J.A. Lowe, S. Brown, P. Vellinga, D. de Gusmao, J. Hinkel and R.S.J. Tol (2011) Sea-level rise and its possible impacts given a 'beyond $4^{\circ} \mathrm{C}$ world' in the twenty-first century, Philosophical Transactions of the Royal Society A 369(1934): 161-181.

Nolet, E. (2018) A tsunami from the mountains: Interpreting the Nadi floods in Fiji, in T. Crook and P. Rudiak-Gould (eds.) Pacific Climate Cultures: Living Climate Change in Oceania. De Gruyter.

Nunn, P., Aalbersberg, W., Lata, S., Gwilliam, M. (2014) Beyond the core: community governance for climate-change adaptation in peripheral parts of Pacific Island Countries, Regional Environmental Change 14: 221-235.

Nunn, P., Kumar, R. (2018) "Understanding climate-human interactions in Small Island Developing States (SIDS): Implications for future livelihood sustainability", International Journal of Climate Change Strategies and Management, 10(2): 245-271.

This article is protected by copyright. All rights reserved. 
Nurse, L.A., J. McLean, R. Agard et al. (2014) Small Islands, in Climate Change 2014: Impacts, Adaptation and Vulnerability. Fifth Assessment Report of the Intergovernmental Panel on Climate Change. Cambridge UK: Cambridge University Press.

Office of the President Government of Kiribati, (no date) 'Relocation' Republic of Kiribati, Retrieved 4 May 2018, from website:

http://www.climate.gov.ki/category/action/relocation/

Ourbak, T. and A.K. Magnan (2017) The Paris Agreement and climate change negotiations:

Small Islands, big players. A commentary. Regional Environmental Change, doi.org/10.1007/s10113-017-1247-9. [http://rdcu.be/yvie]

Rakova, U. (2009) How-to guide for environmental refugees. Our World, United Nations University. Retrieved 4 May 2018, from website: http://ourworld.unu.edu/en/how-to-guidefor-environmental-refugees.

Republic of Fiji, (2014) Second national communication to the United Nations Framework Convention on Climate Change. Suva, Fiji: Ministry of Foreign Affairs.

Sim, R., and West, D., (1999) Prehistoric human occupation in the Bass Strait region, southeast Australia: an Aboriginal and an archaeological perspective. The Archaeology and Anthropology of Landscape: Shaping Your Landscape edited by Robert Layton and Peter Ucko 
Siméoni, P., Ballu, V. (2012) The myth of the first "climate refugee": population movement and environmental changes in the Torres Islands (Vanuatu, Melanesia), Annales de Géographie 685: 219-241.

Steiner, C.E. (2015) A sea of warriors: Performing an identity of resilience and empowerment in the face of climate change in the Pacific, The Contemporary Pacific 27(1): 147-180.

Stratford, E., C. Farbotko and H. Lazrus (2013) Tuvalu, sovereignty and climate change: considering Fenua, the archipelago and emigration, Island Studies Journal 8(1): 67-83. Stoffle, R. and R. Arnold (2003) Confronting the Angry Rock: American Indians' Situated Risks from Radioactivity, Ethnos (68)2: 230-248.

Tiimon, M. (2011) The human face of climate change, Compass 3: 25-26. Retrieved 4 May 2018, from website: http://compassreview.org/spring11/5.pdf

Trask, Haunani-Kay. "Natives and anthropologists: The colonial struggle." The Contemporary Pacific (1991): 159-167.

Walshe, R.A. and Nunn, P.D. (2012) Integration of Indigenous Knowledge and Disaster Risk Reduction: A Case Study from Baie Martelli, Pentecost Island, Vanuatu. International Journal of Disaster Risk Science, 2012, 3 (4): 185-194

Weber, E. (2015) Envisioning South-South relations in the fields of environmental change and migration in the Pacific Islands-past, present and futures, Bandung: Journal of the Global South 2(1): 6. 
Wilmsen, B. and M. Webber (2015) What can we learn from the practice of developmentforced displacement and resettlement for organised resettlements in response to climate change?, Geoforum 58: 76-85.

Wilmsen, B. and Wang, M. (2015) Voluntary and involuntary resettlement in China: a false dichotomy?, Development in Practice, 25:5, 612-627.

Zickgraf, Caroline. 2016. "Transnational Ageing and the 'Zero Generation': The Role of Moroccan Migrants' Parents in Transnational Family Life." Journal of Ethnic \& Migration Studies 43 (2): 321-337

Zickgraf, C. (2018) Immobility. IN Routledge Handbook of Environmental Displacement R., McLeman and F. Gemenne (eds) Routledge 


\section{Voluntary immobility and existential security in a changing climate in the Pacific}

Carol Farbotko $^{1}$ and Celia McMichael ${ }^{2}$

1. CSIRO, CSIRO Ecosystem Sciences, Research Scientist <carol.farbotko@csiro.au>

2. School of Geography, The University of Melbourne.

Abstract. With the expectation of adverse climate change impacts, some (often majority) Indigenous populations of the Pacific are expressing a preference to remain on Indigenous lands for cultural and spiritual reasons. In some cases, Indigenous people express preparedness to die on traditional territory rather than relocate, representing a new type of agency and resistance to dispossession. This is a prominent politics of place of relevance to emerging debates and decision-making around retreat and relocation. If climate change is experienced by populations as an existential threat to culture, identity and place-based connections, voluntary immobility can be an important adaptation strategy that helps to strengthen cultural and spiritual resilience among those facing the prospect of a lost homeland. This paper argues that voluntary immobility decisions need ethically robust and culturally appropriate policies and practices, particularly when a site is deemed by external experts to be no longer fit for human settlement. National governments, civil society groups, international organisations and donors will need to: engage in culturally meaningful dialogue with communities about relocation and immobility; respect, protect, and fulfil the rights of 'immobile' people and those on the move; and confirm that in situ adaptation options have been exhausted.

Keywords: relocation, immobility, migration, climate change, adaptation, Pacific, small island states, Indigenous

This article is protected by copyright. All rights reserved. 


\section{University Library}

\section{- M M I N E R VA A gateway to Melbourne's research publications}

Minerva Access is the Institutional Repository of The University of Melbourne

Author/s:

Farbotko, C;McMichael, C

Title:

Voluntary immobility and existential security in a changing climate in the Pacific

Date:

2019-08-01

Citation:

Farbotko, C. \& McMichael, C. (2019). Voluntary immobility and existential security in a changing climate in the Pacific. ASIA PACIFIC VIEWPOINT, 60 (2), pp.148-162. https:// doi.org/10.1111/apv.12231.

Persistent Link:

http://hdl.handle.net/11343/286903 